\title{
UPAYA MEMINIMALISIR PERKAWINAN ANAK
}

\author{
Susi Susilawati ${ }^{1}$, Baliana Amir ${ }^{2}$, Ratu Ratna Korompot ${ }^{3}$, Marini Citra Dewi ${ }^{4}$ \\ ${ }^{1}$ Dosen Fakultas Hukum Universitas Tadulako \\ Email: susi2lawati78@gmail.com \\ ${ }^{2}$ Dosen Fakultas Hukum Universitas Tadulako \\ Email: baliana.untad@gmail.com \\ ${ }^{3}$ Dosen Fakultas Hukum Universitas Tadulako \\ Email: raturatna825@gmail.com \\ ${ }^{4}$ Dosen Fakultas Hukum Universitas Tadulako \\ Email: marinicitradewi11@gmail.com
}

\begin{abstract}
This paper is based on the results of community service. Research results and information on social media prove a significant increase in the number of child marriages. The rise of child marriages in Palu City since the Amendment to the Marriage Law (UUP) is the background for holding this activity. With the aim of helping the Government socialize the latest UUUP and as an effort to minimize child marriage. The implementation method is in the form of a seminar with several resource persons, namely the Service Team itself, namely academics from the Faculty of Law, Tadulako University, Civil Law Section.
\end{abstract}

Keywords: Socialization, Marriage, Child

\begin{abstract}
Abstrak
Tulisan ini berdasarkan hasil pengabdian pada masyarakat. Hasil penelitian pun dan informasi-informasi di media sosial membuktikan adanya peningkatan yang cukup signifikan jumlah peristiwa perkawinan anak. Maraknya perkawinan anak di Kota Palu sejak Amandemen Undang-Undang Perkawinan (UUP) sebagai latar belakang diadakannya kegiatan ini. Dengan tujuan untuk membantu Pemerintah mensosialisasikan UUP terbaru dan sebagai upaya meminimalisir perkawinan anak. Metode Pelaksanaannya dalam bentuk seminar dengan beberapa Narasumber yaitu Tim Pengabdi sendiri yaitu para akademisi dari Fakultas Hukum Unversitas Tadulako Bagian Hukum Perdata.
\end{abstract}

Kata Kunci: Sosialisasi, Perkawinan, Anak.

\section{A. Pendahuluan}

Undang-Undang Nomor 16 Tahun 2019 adalah Undang-Undang tentang Perubahan atas Undang-Undang Nomor 1 Tahun 1974 tentang 
Perkawinan. Pasal yang diubah hanyalah pasal tentang batas minimal usia kawin bagi perempuan. Semula 16 tahun. Terbaru 19 tahun. Perubahan tersebut tentunya membawa angin segar dan penyemangat bagi penggiat dan pejuang hak-hak perempuan. Salah satu perjuangannya mampu menggoyahkan dan mengubah Pasal 7 Ayat (1) Undang-Undang Perkawinan tentang batas usia kawin.

Perjuangan kaum perempuan dalam hal penggantian pasal-pasal Undang-Undang Perkawinan (selanjutnya disebut UUP) yang dianggap bias jender, masih harus bersabar. Perubahan satu saja bagi mereka merupakan anugrah yang tak terhingga karena kerasnya perjalanan untuk sampai kesitu. 47 tahun, UUP baru bisa berubah. Itupun hanya 1 Pasal. Jika demikian, bisa dibayangkan perubahan beberapa pasal akan membutuhkan waktu berapa lama. ${ }^{1}$

UUP ini diterbitkan dan mulai berlaku bulan Oktober 2019, lebih 2 tahun lalu, namun keberadaannya cukup membuat Pengadilan Agama kebanjiran permohonan dispensasi kawin, khususnya di Kota Palu. ${ }^{2}$ Belum lagi yang tidak bermohon ke Pengadilan yang disebabkan sesuatu dan lain hal. Alasan-alasan masyarakat yang bermohon dispensasi kawin terbanyak dikarenakan calon pengantin perempuannya sudah hamil. ${ }^{3}$

Dispensasi atau rukhshah merupakan pengecualian dari suatu ketentuan yang sudah baku untuk keadaan tertentu. ${ }^{4}$ Dispensasi kawin diajukan apabila pasangan calon pengantin atau salah satunya belum mencapai umur 19 tahun. Sebelum mengajukan permohonan, mereka ke

${ }^{1}$ Beberapa pasal UUP yang tidak berkesetaraan jender. Lihat Susi Susilawati. 2019. Kesetaraan Jender dalam membangun Hukum Perkawinan yang Berkeadilan. Disertasi yang tidak dipublikasi, viii.

2 Ashar Ridwan dkk, Permohonan Dispensasi Perkawinan Pasca Amandemen UU Perkawinan di Pengadilan Agama Kota Palu, Hasil Penelitian, (tahun 2020), 19.

${ }^{3}$ Sahran Raden Ribhan, Abd. M. Aso, Hilal Malarangan, 'Alasan Dispensasi Nikah Usia Dini (Studi Kasus Di Pengadilan Agama Palu )', Familia: Jurnal Hukum Keluarga, 1 (2020), 146-151.

${ }^{4}$ A. Kadir, Perspektif Baru Hukum Perkawinan Islam Nikah, Talak, Rujuk. (Fatawa Publishing, Semarang, 2020), 130. 
Kantor Urusan Agama (untuk Muslim) terlebih dahulu. Agar mendapat surat penolakan dari KUA yang disebabkan usia mereka atau salah satu calon pengantin belum sampai 19 tahun. Hal inilah yang belum banyak diketahui masyarakat. Sehingga membutuhkan sosialisasi secara intensif pada semua kalangan.

\section{B. Pembahasan}

\section{Hukum Perkawinan di Indonesia}

Pluralisme dalam hukum perkawinan telah disatukan atau diunifikasi ke dalam UUP. Dengan lahirnya Undang-Undang Nomor 1 Tahun 1974 sebagaimana telah diubah ke dalam UU Nomor 16 Tahun 2019 tentang Perkawinan, maka hukum perkawinan manapun harus tunduk padanya. Namun, kenyataannya UUP ini masih menampilkan pluralismenya yakni pada Pasal 2 dan Pasal 66. Pasal 2 UUP tentang pluralisme dengan perbedaan agama dan kepercayaan. Sedangkan Pasal 66 disebabkan UUP tidak secara tuntas mengatur materi perkawinan. Olehnya, UUP masih perlu perbaikan dan pembaharuan.

Perkawinan menurut Hukum Perdata adalah suatu perbuatan hukum yang dilakukan pada suatu saat tertentu. ${ }^{5}$ Definisi tersebut terdengar sangat umum. Jika pengertiannya demikian maka, bukan hanya peristiwa perkawinan namun juga peristiwa lainnya pun dapat diartikan seperti itu.

Pasal 26 KUHPerdata menjelaskan bahwa UU memandang perkawinan hanya dalam hubungan-hubungan keperdataan saja. Dengan demikian, menurut KUHPerdata, keabsahan sebuah perkawinan jika memenuhi persyaratan yang ditetapkan olehnya, sementara persyaratan agama dikesampingkan. Kebalikan dari keabsahan menurut Pasal 2 UUP.

UUP mendefinisikan perkawinan dengan ikatan lahir batin antara pria dan wanita sebagai suami istri dengan tujuan untuk membentuk keluarga (rumah tangga) yang bahagia dan kekal berdasarkan Ketuhanan Yang Maha

\footnotetext{
${ }^{5}$ Pasal 104, 209 sub BW. KUHPer.
} 
Esa. ${ }^{6}$ Pengertian lahir batin tidak boleh dipisahkan. Keduanya sangat penting dalam membangun sebuah keluarga. Ikatan lahir sebagai ikatan yang dapat dilihat dan mengungkapkan hubugan hukum antara seorang pria dan seorang wanita untuk hidup bersama sebagai suami istri (formal). Sedangkan ikatan batin merupakan hubungan non formal. Hubungan yang tidak tampak, tidak nyata, yang hanya dirasakan oleh pihak-pihak yang mengikatkan dirinya dengan yang lain. Ikatan batin adalah dasar ikatan lahir. Sebagai fondasi dalam membentuk dan membina keluarga yang bahagia dan kekal.

UUP di atas menyebutkan pria dan wanita. Dengan pengertian bahwa di Indonesia hanya membolehkan perkawinan antara pria dan wanita, tidak untuk perkawinan sejenis baik itu pria dengan pria/gay, wanita dengan wanita/lesbi, ataupun waria dengan waria.

Suami istri merupakan sebuah persekutuan hukum. Keduanya harus melalui perkawinan yang sah. Sah secara agama maupun diakui Negara. Begitulah amanat UUP Pasal 2. Asas yang dianut UUP adalah asas monogami terbuka. Artinya bahwa pada dasarnya seorang suami atau seorang istri hanya bisa menikahi seorang saja. Namun, diberi kelonggaran bagi seorang suami untuk menikahi lebih dari seorang istri dengan syarat dan ketentuan berlaku. Sebagaimana di atur dalam Pasal 3 sampai Pasal 5 UUP.

Rumah tangga yang bahagia dan kekal adalah idaman semua keluarga. Namun dalam prosesnya pasti menemukan kendala sebagai ujian yang harus dilaluinya. Kebahagiaan dan kesejahteraan penghuni rumah merupakan hal utama. Jika tak lagi ditemukan keduanya maka perceraian sebagai jalan terakhir untuk melewatinya. Pasangan yang cukup umur, siap mental, dan melimpah materi bisa dilanda perceraian, apalagi suami istri yang masih belia dan tak punya apa-apa untuk bekal pertahanan diri baik secara mental maupun spiritual terlebih materi. Olehnya, perkawinan anak perlu dihindari demi kebahagiaan dan keabadian rumah tangga itu sendiri. Bukan hanya perceraian menanti, tapi juga kematian setelah melahirkan bagi perempuan

${ }^{6}$ Pasal 1 UUP 
yang usianya masih terbilang dini. Atas dasar itu sosialisasi ini diselenggarakan. Ikhtiar agar rumah tangga bahagia dan kekal abadi.

Perkawinan adalah peristiwa yang sangat penting dalam mengarungi kehidupan ini. Generasi manusia akan tumbuh dan berkembang melalui proses perkawinan. Berbeda dengan makhluk lainnya yang tidak diberi Tuhan akal, maka manusia menciptakan lembaga atau instansi perkawinan yang selaras dengan perintah agama. Dengan demikian, masalah perkawinan dan aturan-aturan yang menyertainya sangat urgen untuk dibahas dan disosialisasikan kepada masyarakat. Terkait dengan kegiatan pengabdian ini.

Hukum perkawinan di Indonesia sangatlah plural. Kemajemukkannya telah berhasil di unifikasi dalam Undang-Undang Perkawinan. Apapun hukumnya, baik hukum perkawinan Perdata, perkawinan Islam, dan perkawinan Adat harus tunduk pada Undang-Undang Nomor 16 Tahun 2019 tentang Perubahan atas Undang-Undang Nomor 1 Tahun 1974 tentang Perkawinan (UUP).

Walau baru dua kali diterbitkan namun, problematika di dalamnya sangatlah beragam dan banyak. Senyatanya memang begitu, karena kehidupan perkawinan adalah hal yang dialami dan dirasakan oleh setiap manusia. Baik sebagai pasangan, orang tua, dan juga sebagai anak dari sebuah keluarga. Problematika yang terjadi bukan hanya pada redaksi Undang-Undang namun juga pada ketegasan sanksi, perkawinan beda agama, perkawinan sejenis, perkawinan siri, dan perkawinan kontrak. ${ }^{7}$ Ditambah permasalahan baru pasca Amandemen UUP yakni perkawinan anak. Maraknya perkawinan anak terjadi setelah perubahan Pasal 7 Ayat 1 UUP ini. ${ }^{8}$ Dengan demikian, sosialisasi UUP terbaru sangatlah diperlukan.

${ }^{7}$ Novita Lestari, Sawah Lebar, and Ratu Agung, 'Problematika Hukum Perkawinan Di Indonesia', 4.32 (2017), 43.

${ }^{8}$ Susi Susilawati, Ashar Ridwan, and Sitti Fatimah Madusila, 'CRIMINAL LIABILITY AGAINST PERPETRATORS OF FRAUDULENT CRIMINAL ACT BY HYNOSIS Susi Susilawati 1 , Ashar Ridwan 2 , Sitti Fatimah Madusila 3', 6.1 (2021), 40-49. 


\section{Pencatatan Nikah}

Undang-Undang Nomor 22 Tahun 1946 jo. Undang-Undang Nomor 32 Tahun 1954 tentang Pencatatan Nikah Pasal 1 Ayat 1 menyatakan bahwa nikah yang dilakukan menurut agama Islam diawasi oleh pegawai pencatat nikah yang diangkat oleh Menteri agama atau Pegawai yang ditunjuk olehnya. UUP menempatkan pencatatan suatu perkawinan pada kedudukan yang penting sebagai pembuktian telah diadakan perkawinan. Pasal 2 Ayat 2 UUP menyebutkan tiap-tiap perkawinan dicatat menurut peraturan perundang-undangan yang berlaku.

Pencatatan nikah bukanlah sesuatu hal yang menentukan sah atau tidak sahnya suatu perkawinan. Keabsahan perkawinan ditentukan oleh agamanya masing-masing walaupun tidak atau belum dicatatkan. jika rukun nikah telah lengkap, tetapi tidak didaftar maka nikah tersebut adalah sah, sedang yang bersangkutan dikenakan denda karena nikah tidak didaftar. ${ }^{9}$

Bab 3 PP No 9 Tahun 1975 mengenai Tatacara Perkawinan, Pasal 10 Ayat 1 menentukan bahwa perkawinan dilangsungkan setelah hari kesepuluh sejak pengumuman kehendak perkawinan oleh pegawai pencatat. Caranya dengan menempelkan surat pengumuman pada kantor pencatat perkawinan. Jika sekarang zamannya teknologi informasi digital, maka seyogyanya diumumkan di laman web atau link KUA bagi Muslim atau media sosial lainnya. Sedangkan Ayat 2 menyebutkan bahwa tatacara perkawinan dilakukan menurut hukum masing-masing agamanya dan kepercayaannya itu. Setelah perkawinan itu sah menurut agamanya, kedua mempelai menandatangani akta perkawinan. Akta perkawinan tersebut selain ditandatangani mempelai, ditandatangani juga oleh 2 orang saksi, Wali, dan Pegawai Pencatat Nikah yang menghadiri perkawinan. Dengan demikian, perkawinan telah tercatat secara resmi.

${ }_{9}^{9}$ SK Mahkamah Islam Tinggi Tahun 1953 no. 23/19. 
Kompilasi Hukum Islam (KHI) mewajibkan pencatatan nikah bagi seorang muslim. ${ }^{10}$ Jika perkawinan belum dicatatkan dan diperlukan bukti akta nikah, maka solusi yang ditawarkan adalah isbat nikah atau penetapan tentang nikah. Sebenarnya, ada hukuman bagi pelaku pelanggar Pencatatan Perkawinan. Peraturan Pemerintah No 9 Tahun 1975 memberikan sanksi denda terhadapnya. Sejumlah Rp. 7.500,00. Namun, hal ini tak pernah dipatuhi. Perlu sanksi tegas lagi untuk sang pelaku, agar bangsa Indonesia tertib administrasi.

Penghulu merupakan aktor dalam peristiwa pencatatan nikah. Penghulu adalah Pegawai Negeri Sipil sebagai pencatat nikah yang diberi tugas, tanggung jawab, wewenang dan hak secara penuh oleh Menteri Agama atau pejabat yang ditunjuk sesuai peraturan perundang-undangan yang berlaku untuk melakukan pengawasan nikah rujuk menurut Agama Islam dan kegiatan kepenghuluan. ${ }^{11}$ Perkawinan yang dicatat adalah perkawinan yang sesuai aturan atau UUP. Bilamana terdapat pelanggaran, maka Penghulu wajib menertibkannya. Baik dengan cara penolakan maupun dengan cara memberikan nasehat berupa arahan dan solusi.

Dalam Al-Quran Surat al-Baqarah (2) Ayat 282, yang intinya adalah “jika kamu bermuamalah, maka catat dan hadirkan 2 orang saksi”. Begitulah pentingnya pencatatan dalam bermuamalah. Baik mengenai utang piutang maupun perkawinan.

Pendapat para ahli hukum pun demikian. Sebaiknya perkawinan itu dicatat. Apalagi perkawinan yang telah memenuhi rukun dan syarat perkawinan menurut agama. Agar diketahui dan diakui negara, maka dicatatkan. Jika tidak dicatat berakibat pada hubungan hukum antara suami, istri dan anak-anak yang dilahirkan. Anak hanya mempunyai hubungan

\footnotetext{
10 Pasal 5, 6, dan 7.

11 Departemen Agama, Himpunan Peraturan Perundang - Undangan Bidang Urusan Agama (Banda Aceh: Bidang Urusan Agama Islam Kantor Wilayah Departemen Agama, 2009), 440.
} 
perdata dengan ibunya saja. Sedangkan istri tidak dapat menuntut haknya melalui jalur hukum negara.

\section{Amandemen UUP}

Pertimbangan dalam UU 16 Tahun 2019 tentang Perubahan Atas UU 1

Tahun 1974 tentang Perkawinan adalah:

a. Negara menjamin hak warga negara untuk membentuk keluarga dan melanjutkan keturunan melalui perkawinan yang sah, menjamin hak anak atas kelangsungan hidup, tumbuh, dan berkembang serta berhak atas perlindungan dari kekerasan dan diskriminasi sebagaimana diamanatkan dalam Undang-Undang Dasar Negara Republik Indonesia Tahun 1945;

b. Perkawinan pada usia anak menimbulkan dampak negatif bagi tumbuh kembang anak dan akan menyebabkan tidak terpenuhinya hak dasar anak seperti hak atas perlindungan dari kekerasan dan diskriminasi, hak sipil anak, hak kesehatan, hak pendidikan, dan hak sosial anak;

c. Sebagai pelaksanaan atas putusan Mahkamah Konstitusi Republik Indonesia Nomor 22/PUU-XV/2017 perlu melaksanakan perubahan atas ketentuan Pasal 7 Undang-Undang Nomor 1 Tahun 1974 tentang Perkawinan;

d. Berdasarkan pertimbangan sebagaimana dimaksud dalam huruf $a$, huruf $b$, dan huruf c, perlu membentuk Undang-Undang tentang Perubahan atas Undang-Undang Nomor 1 Tahun 1974 tentang Perkawinan;

Dasar hukum UU 16 Tahun 2019 tentang Perubahan Atas UU 1 Tahun 1974 tentang Perkawinan adalah

1. Pasal 5 ayat (1), Pasal 20, dan Pasal 28B Undang-Undang Dasar Negara Republik Indonesia Tahun 1945;

2. Undang-Undang Nomor 1 Tahun 1974 tentang Perkawinan (Lembaran Negara Republik Indonesia Tahun 1974 Nomor 1, Tambahan Lembaran Negara Republik Indonesia Nomor 3019);

Dalam ketentuan Pasal 28B Undang-Undang Dasar Negara Republik Indonesia Tahun 1945, dicantumkan bahwa setiap orang berhak membentuk 
keluarga dan melanjutkan keturunan melalui perkawinan yang sah serta Negara menjamin hak anak atas kelangsungan hidup, tumbuh, dan berkembang serta berhak atas pelindungan dari kekerasan dan diskriminasi.

Pasal 7 ayat (1) Undang-Undang Nomor 1 Tahun 1974 menyatakan bahwa perkawinan hanya diizinkan apabila pihak pria mencapai umur 19 (sembilan belas) tahun dan pihak wanita sudah mencapai usia 16 (enam belas) tahun, ketentuan tersebut memungkinkan terjadinya perkawinan dalam usia anak pada anak wanita karena dalam Pasal 1 angka 1 UndangUndang tentang Perubahan Atas Undang-Undang Nomor 23 Tahun 2002 tentang Pelindungan Anak didefinisikan bahwa anak adalah seseorang yang belum berusia 18 (delapan belas) tahun, termasuk anak yang masih dalam kandungan.

Mahkamah Konstitusi Republik Indonesia telah mengeluarkan Putusan Mahkamah Konstitusi Nomor 22/PUU-XV/2017 yang salah satu pertimbangan Mahkamah Konstitusi dalam putusan tersebut yaitu "Namun tatkala pembedaan perlakuan antara pria dan wanita itu berdampak pada atau menghalangi pemenuhan hak-hak dasar atau hak-hak konstitusional warga negara, baik yang termasuk ke dalam kelompok hak-hak sipil dan politik maupun hak-hak ekonomi, pendidikan, sosial, dan kebudayaan, yang seharusnya tidak boleh dibedakan semata-mata berdasarkan alasan jenis kelamin, maka pembedaan demikian jelas merupakan diskriminasi." Dalam pertimbangan yang sama juga disebutkan Pengaturan batas usia minimal perkawinan yang berbeda antara pria dan wanita tidak saja menimbulkan diskriminasi dalam konteks pelaksanaan hak untuk membentuk keluarga sebagaimana dijamin dalam Pasal 28B ayat (1) UUD 1945, melainkan juga telah menimbulkan diskriminasi terhadap pelindungan dan pemenuhan hak anak sebagaimana dijamin dalam Pasal 28B ayat (2) UUD 1945. Dalam hal ini, ketika usia minimal perkawinan bagi wanita lebih rendah dibandingkan pria, maka secara hukum wanita dapat lebih cepat untuk membentuk keluarga. Oleh karena hal tersebut, dalam amar putusannya Mahkamah Konstitusi 
memerintahkan kepada pembentuk undang-undang untuk dalam jangka waktu paling lama 3 (tiga) tahun melakukan perubahan terhadap UndangUndang Nomor 1 Tahun 1974 tentang Perkawinan.

Perubahan norma dalam Undang-Undang Nomor 1 Tahun 1974 tentang Perkawinan ini menjangkau batas usia untuk melakukan perkawinan, perbaikan norma menjangkau dengan menaikkan batas minimal umur perkawinan bagi wanita. Dalam hal ini batas minimal umur perkawinan bagi wanita dipersamakan dengan batas minimal umur perkawinan bagi pria, yaitu 19 (sembilan belas) tahun. Batas usia dimaksud dinilai telah matang jiwa raganya untuk dapat melangsungkan perkawinan agar dapat mewujudkan tujuan perkawinan secara baik tanpa berakhir pada perceraian dan mendapat keturunan yang sehat dan berkualitas. Diharapkan juga kenaikan batas umur yang lebih tinggi dari 16 (enam belas) tahun bagi wanita untuk kawin akan mengakibatkan laju kelahiran yang lebih rendah dan menurunkan resiko kematian ibu dan anak. Selain itu juga dapat terpenuhinya hak-hak anak sehingga mengoptimalkan tumbuh kembang anak termasuk pendampingan orang tua serta memberikan akses anak terhadap pendidikan setinggi mungkin.

UUP bukanlah kitab suci yang tak akan pernah berubah. Perkembangan yang terjadi dalam masyarakat menuntut adanya pembaharuan hukum terutama hukum perkawinan. Sebagaimana yang terjadi pada persyaratan poligami, persyaratan perceraian, dan hubungan keperdataan anak hasil nikah siri. Semuanya mengalami pembaharuan. ${ }^{12}$ Termasuk batas minimal usia menikah bagi perempuan. Bukan hanya judicial review atau Keputusan Mahkamah Konstitusi, namun langsung mengubah UU terdahulu. Meskipun hanya satu pasal. Berdasarkan itu, betapa pentingnya UUP terbaru ini. Jika UUP tersebut benar-benar terealisasi maka terwujudlah tujuannya yaitu memenuhi amanat dari UUD 45 tentang hak asasi manusia,

12 Pengadilan Tinggi and others, 'PEMBAHARUAN HUKUM PERKAWINAN DI INDONESIA Mukhlis', 1, 2015, 59. 
perlindungan terhadap anak, dan pemenuhan hak anak. ${ }^{13}$

\section{Dispensasi Kawin}

DPR telah mensahkan Undang-Undang Nomor 16 Tahun 2019 tentang perubahan Undang-Undang Nomor 1 Tahun 1974 tentang Perkawinan, yaitu perkawinan hanya diizinkan apabila pria dan wanita sudah mencapai umur 19 (Sembilan belas) tahun. Pada ayat selanjutnya, dalam hal terjadi penyimpangan terhadap ketentuan umur sebagaimana dimaksud pada ayat (1), orang tua pihak pria dan/atau orang tua pihak wanita dapat meminta dispensasi kepada Pengadilan dengan alasan sangat mendesak disertai buktibukti pendukung yang cukup. Dengan lahirnya Undang-Undang ini, memberikan pengertian bahwa peningkatan batas usia perkawinan bagi perempuan menjadi 19 tahun dan masih diberinya peluang pengajuan dispensasi nikah jika usia calon pasang belum mencapai 19 tahun.

Prosedur pengajuan perkara dispensasi di Pengadilan Agama sama dengan mekanisme pengajuan perkara permohonan lainnya, adapun prosedurnya berdasarkan Buku II tentang Pedoman Pelaksanaan Tugas dan Administrasi Peradilan Agama adalah sebagai berikut;

a. Permohonan dispensasi kawin diajukan oleh calon mempelai pria yang belum berusia 19 tahun, calon mempelai wanita yang belum berusia 19 tahun dan/atau orang tua calon mempelai tersebut kepada Pengadilan Agama/Mahkamah Syar'iyah dalam wilayah hukum dimana calon mempelai dan/atau orang tua calon mempelai tersebut bertempat tinggal.

b. Permohonan dispensasi kawin yang diajukan oleh calon mempelai pria dan/atau calon mempelai wanita dapat dilakukan secara bersama-sama kepada pengadilan agama/mahkamah syar'iyah dalam wilayah hukum dimana calon mempelai pria dan wanita tersebut bertempat tinggal.

c. Pengadilan Agama/Mahkamah Syar'iyah dapat memberikan dispensasi kawin setelah mendengar keterangan dari orang tua, keluarga dekat atau walinya.

13 Undang-Undang Dasar Negara and Republik Indonesia, 'LEMBARAN NEGARA', No. 186, 2019. 
d. Permohonan dispensasi kawin bersifat voluntair produknya berbentuk penetapan. Jika Pemohon tidak puas dengan penetapan tersebut, maka Pemohon dapat mengajukan upaya kasasi.

e. Para Pemohon mengajukan permohonan dispensasi kawin ke meja pendaftaran jika permohonannya telah selesai dibuat, jika belum dibuat maka bisa dibuat permohonan di Posbakum (Pos bantuan hukum).

f. Meja pendaftaran akan meneliti berkas yang diajukan (surat permohonan, identitas pemohon), kemudian menaksir panjar biaya perkara dan menulisnya dalam Surat Kuasa Untuk Membayar (SKUM), besarnya panjar biaya perkara diperkirakan harus telah mencukupi untuk menyelesaikan perkara tersebut.

g. Berkas tersebut lanjut ke meja Kasir, kemudian;

1. Menandatangani dan memberi nomor urut dan tanggal penerimaan perkara dalam SKUM dan dalam surat permohonan.

2. Pemohon melakukan pembayaran ke bank.

3. Setelah pemohon membayar panjar perkara, kasir memberi tanda lunas dalam SKUM.

h. Meja Pendaftaran, memberi nomor yang diberikan kasir sebagai tanda telah terdaftar maka diberi paraf, kemudian menyerahkan salah satu surat permohonan yang telah terdaftar bersama satu helai SKUM kepada pemohon.

i. Perkara dispensasi kawin telah terdaftar di Pengadilan Agama, Panitera menyampaikan kepada Ketua Pengadilan Agama untuk menetapkan majelis hakim yang akan memeriksa dan memutus perkara tersebut.

j. Panitera menunjuk Panitera Pengganti dan Jurusita Pengganti untuk membantu majelis hakim.

k. Majelis Hakim setelah menerima berkas perkara, bersama-sama hakim anggotanya mempelajari berkas perkara, kemudian menetapkan hari dan tanggal serta jam kapan perkara itu disidangkan serta memerintahkan 
agar para pihak dipanggil untuk datang menghadap pada hari, tanggal dan jam yang telah ditentukan.

l. Pemohon akan menunggu relaas panggilan dari Juru sita/Jurusita Pengganti, setelah ketua majelis menetapkan hari sidang.

Prosedur di atas harus dilalui oleh para pemohon dispensasi kawin. Dengan demikian, bukan hanya sehari untuk mengurus dispensasi tersebut. Jika rumahnya dekat dengan Pengadilan tentu tidak masalah. Namun, bagi masyarakat yang jauh domisilinya dengan Pengadilan, tentunya harus dicarikan solusi agar mereka tetap melaksanakan apa yang diperintahkan UU. Sebab, jika tidak demikian, maka pelanggaran terhadap UU itu akan semakin nyata.

Solusi hukum yang ditawarkan Negara untuk yang terdesak menikah di usia belia, di bawah 19 tahun, adalah dispensasi kawin. Dispensasi kawin merupakan pintu darurat, agar perkawinan anak dapat dicatat oleh Negara.

Anak adalah amanah dan karunia Tuhan yang Maha Esa. Mereka memiliki harkat dan martabat sebagai manusia seutuhnya. Olehnya, Ia memiliki hak yang sama untuk tumbuh dan berkembang. ${ }^{14}$ Hak-hak yang dimiliki anak tersebut dilindungi oleh negara. Berdasarkan itu, dikeluarkannya Perma Nomor 5 Tahun 2019 tentang Pedoman Mengadili Permohonan Dispensasi Kawin.

Perma tersebut dijadikan landasan dan acuan oleh Pengadilan dan Kantor Urusan Agama (KUA) dalam hal dispensasi kawin. Sebelum ke Pengadilan Agama, bagi seorang muslim, harus mendapatkan surat penolakan terlebih dahulu dari KUA. Sebagai landasan untuk bermohon dispensasi kawin.

Pengadilan adalah tempat pencari keadilan. Seyogyanya masyarakat merasa aman dan nyaman dengan tempat itu. Namun, kenyataannya bagi sebagian masyarakat, Pengadilan adalah tempat yang paling menyeramkan. Sehingga banyak yang anti terhadapnya. Atas dasar itu, permohonan Kawin

${ }^{14}$ Perma Nomor 5 Tahun 2019 tentang Pedoman Mengadili Permohonan Dispensasi 
dispensasi kawin adalah hal yang memberatkan dan menjadi faktor penghambat dalam efektivitas pengajuan dispensasi kawin. Walaupun demikian, hasil penelitian menunjukan bahwa adanya peningkatan permohonan dispensasi kawin di Pengadilan secara signifikan pasca Amandemen UUP. ${ }^{15}$

\section{Penutup}

Perkawinan anak seyogyanya dihindari, karena mudhorat yang ditimbulkan lebih besar dari manfaatnya. Sosialisasi dan penyuluhan hukum perkawinan yang intensif perlu terus digaungkan agar masyarakat semakin terkondisikan untuk mentaati segala aturan yang sudah ditetapkan. Hukum Perkawinan yang berlaku di Indonesia bertujuan untuk kemaslahatan masyarakat itu sendiri. Dalam menciptakan dan mewujudkan keluarga yang sakinah, mawaddah, dan rahmah.

\section{DAFTAR PUSTAKA}

Abd. M. Aso, Ribhan, Malarangan, Hilal, Raden, Sahran, 'Alasan Dispensasi Nikah Usia Dini (Studi Kasus Di Pengadilan Agama Palu )', Familia: Jurnal Hukum Keluarga, 12020

Ashar Ridwan dkk. Permohonan Dispensasi Nikah Pasca Amandemen UndangUndang Perkawianan di Kota Palu. Hasil Penelitian Dosen Fakultas Hukum UNTAD, Palu, 2020

Badan Litbang dan Diklat Kementerian Agama RI. Al-Qur'an dan Terjemahan. Bandung, 2019

Departemen Agama, Himpunan Peraturan Perundang - Undangan Bidang Urusan Agama. Banda Aceh: Bidang Urusan Agama Islam Kantor Wilayah Departemen Agama, 2009

${ }^{15}$ Ashar Ridwan dkk, Permohonan Dispensasi Perkawinan......., 19. 
Faruk. Pengantar Sosiologi Sastra. Edisi Revisi. Yogyakarta: Pustaka Pelajar, 2014

Kadir, A. Perspektif Baru Hukum Perkawinan Islam Nikah, Talak, Rujuk. Fatawa Publishing: Semarang, 2020

Lestari, Novita, Sawah Lebar, and Ratu Agung, 'Problematika Hukum Perkawinan Di Indonesia', 4.32. 2017

Susilawati, Susi, Kesetaraan Jender dalam membangun Hukum Perkawinan yang Berkeadilan. Disertasi yang tidak dipublikasi, 2019

Susilawati, Susi, Ashar Ridwan, and Sitti Fatimah Madusila, 'CRIMINAL LIABILITY AGAINST PERPETRATORS OF FRAUDULENT CRIMINAL ACT BY HYNOSIS Susi Susilawati 1 , Ashar Ridwan 2, Sitti Fatimah Madusila 3', 6.1. 2021

Undang-Undang Nomor 16 Tahun 2019 Tentang Perubahan atas UndangUndang Nomor 1 Tahun 1974 Tentang Perkawinan.

Undang-Undang Nomor 32 Tahun 1954 Tentang Pencatatan Nikah Talak dan Rujuk

Undang-Undang Dasar Negara Republik Indonesia, 'LEMBARAN NEGARA', 186, 2019

Peraturan Pemerintah Nomor 9 Tahun 1975 Tentang Pelaksanaan UndangUndang Nomor 1 Tahun 1974 tentang Perkawinan

Peraturan Menteri Agama Nomor 20 tahun 2019 tentang Pencatatan PernikahanAgama, Departemen, Himpunan Peraturan Perundang Undangan Bidang Urusan Agama, Banda Aceh: Bidang Urusan Agama Islam Kantor Wilayah Departemen Agama, 2009

Pengadilan Tinggi Agama Jambi, Jalan H Agus, Salim Kota, Baru Jambi, and Ahmad Zaenal Fanani, 'PEMBAHARUAN HUKUM PERKAWINAN DI INDONESIA Mukhlis', 1, 2015 